\title{
Chemistry of dihydrogen complexes containing only phosphorus co-ligands
}

\author{
BALAJI R JAGIRDAR* and NISHA MATHEW \\ Department of Inorganic and Physical Chemistry, Indian Institute of Science, \\ Bangalore 560 012, India \\ e-mail: jagirdar@ipc.iisc.ernet.in
}

\begin{abstract}
A series of new dicationic dihydrogen complexes of ruthenium of the type $c i s-\left[(\mathrm{dppm})_{2} \mathrm{Ru}\left(\eta^{2}-\mathrm{H}_{2}\right)(\mathrm{L})\right]\left[\mathrm{BF}_{4}\right]_{2}\left(\mathrm{dppm}=\mathrm{Ph}_{2} \mathrm{PCH}_{2} \mathrm{PPh}_{2} ; \mathrm{L}=\right.$ phosphite $)$ have been prepared by protonating the precursor hydride complexes cis$\left[(\mathrm{dppm})_{2} \mathrm{Ru}(\mathrm{H})(\mathrm{L})\right]\left[\mathrm{BF}_{4}\right]$ using $\mathrm{HBF}_{4} \bullet \mathrm{Et}_{2} \mathrm{O}$. The precursor hydride complexes have been obtained from trans- $\left[(\mathrm{dppm})_{2} \mathrm{Ru}(\mathrm{H})(\mathrm{L})\right]\left[\mathrm{BF}_{4}\right](\mathrm{L}=$ phosphite $)$ via a rare acidcatalysed isomerization reaction in six coordinate species. The trans$\left[(\mathrm{dppm})_{2} \mathrm{Ru}(\mathrm{H})(\mathrm{L})\right]\left[\mathrm{BF}_{4}\right]$ complexes $(\mathrm{L}=$ phosphine $)$ upon protonation gave the isomerized derivatives, however, further addition of acid resulted in a five-coordinate species, $\left[(\mathrm{dppm})_{2} \mathrm{RuCl}\right]^{+}$presumably via an intermediate phosphine dihydrogen complex. The electronic as well as the steric properties of the co-ligands seem to strongly influence the structure-reactivity behaviour of this series of complexes.
\end{abstract}

Keywords. Hydrogen; hydride ligands; NMR spectroscopy; ruthenium.

\section{Introduction}

The nature of the ancillary ligand environment in a dihydrogen complex can have a profound effect on the structure and reactivity of the dihydrogen ligand. A thorough understanding of the structure and reactivity of the dihydrogen complexes is required for the rational design of new homogeneous metal catalysts. In this context, transition metal complexes bearing phosphorus co-ligands allows for a very systematic study because both electronic as well as the steric properties of the phosphorus ligands could be varied systematically ${ }^{1}$. We have earlier reported the influence of the cone angles and the $\pi$ acceptor properties of certain phosphorus ligands on the structure and reactivity of a series of dihydrogen complexes of ruthenium of the type trans-[(dppe $)_{2} \mathrm{Ru}\left(\eta^{2}-\right.$ $\left.\left.\mathrm{H}_{2}\right)(\mathrm{L})\right]\left[\mathrm{BF}_{4}\right]_{2} \quad\left(\text { dppe }=\mathrm{Ph}_{2} \mathrm{PCH}_{2} \mathrm{CH}_{2} \mathrm{PPh}_{2} ; \mathrm{L}=\text { phosphite, phosphine }\right)^{2}$. Morris and coworkers studied the effect of changing the $\mathrm{R}$ substituents in chelating phosphine ligands of certain monocationic dihydrogen complexes trans $\left[\left(\mathrm{R}_{2} \mathrm{PCH}_{2} \mathrm{CH}_{2} \mathrm{PR}_{2}\right)_{2} \mathrm{M}\left(\eta^{2}-\right.\right.$ $\left.\left.\mathrm{H}_{2}\right)(\mathrm{L})\right]^{+3,4}$. Several others have carried out variations in the cis ligands of dihydrogen complexes $\left[(\mathrm{L})_{4} \mathrm{Ru}\left(\eta^{2}-\mathrm{H}_{2}\right)(\mathrm{H})\right]^{+}$to study their influence on the properties of these complexes ${ }^{5-10}$. In this paper, we wish to focus on the chemistry of dihydrogen complexes of the type $\left[(\mathrm{dppm})_{2} \mathrm{Ru}\left(\eta^{2}-\mathrm{H}_{2}\right)(\mathrm{L})\right]\left[\mathrm{BF}_{4}\right]_{2} \quad(\mathrm{dppm}=$ bis-(diphenylphosphino)methane, $\mathrm{L}=$ phosphite or phosphine). We also compare the present results with the ones obtained earlier ${ }^{6}$ with analogous derivatives consisting of dppe ligands in order to understand the

\footnotetext{
*For correspondence
} 
effect of the smaller bite angle of the chelating phosphine ligands (here dppm) on the structure-reactivity behaviour of these complexes.

\section{Results and discussion}

The substitution of dihydrogen ligand in trans- $\left[(\mathrm{dppm})_{2} \mathrm{Ru}(\mathrm{H})\left(\eta^{2}-\mathrm{H}_{2}\right)\right]\left[\mathrm{BF}_{4}\right]$ with a monodentate phosphorus ligand, $\mathrm{L}\left(\mathrm{L}=\mathrm{P}(\mathrm{OMe})_{3}, \mathrm{P}(\mathrm{OEt})_{3}, \mathrm{P}\left(\mathrm{O}^{\mathrm{i}} \mathrm{Pr}\right)_{3}, \mathrm{PMe}_{3}, \mathrm{PMe}_{2} \mathrm{Ph}\right)$ in $\mathrm{CH}_{2} \mathrm{Cl}_{2}$ results in trans-[(dppm $\left.)_{2} \mathrm{Ru}(\mathrm{H})(\mathrm{L})\right]\left[\mathrm{BF}_{4}\right]$ complexes,

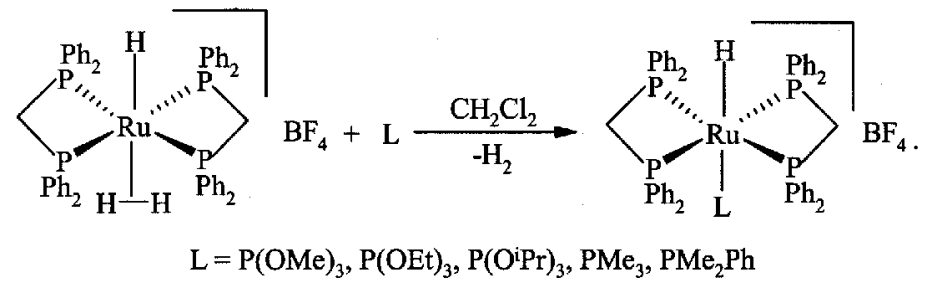

The new hydride complexes were characterized using NMR spectroscopy and elemental analysis and in one case, trans- $\left[(\mathrm{dppm})_{2} \mathrm{Ru}(\mathrm{H})\left(\mathrm{P}(\mathrm{OMe})_{3}\right)\right]\left[\mathrm{BF}_{4}\right]$ complex by X-ray crystallography.

The hydride complexes trans-[(dppm $\left.)_{2} \mathrm{Ru}(\mathrm{H})(\mathrm{L})\right]\left[\mathrm{BF}_{4}\right] \quad\left(\mathrm{L}=\mathrm{P}(\mathrm{OMe})_{3}, \quad \mathrm{P}(\mathrm{OEt})_{3}\right.$, $\left.\mathrm{P}\left(\mathrm{O}^{\mathrm{i}} \mathrm{Pr}\right)_{3}\right)$ were titrated with $\mathrm{HBF}_{4} \cdot \mathrm{Et}_{2} \mathrm{O}$ in $\mathrm{CD}_{2} \mathrm{Cl}_{2}$ under an atmosphere of $\mathrm{H}_{2}$ and the reactions were studied using NMR spectroscopy. Upon addition of one equivalent of the acid, the trans hydride phosphite complexes underwent isomerization resulting in new cis- $\left[(\mathrm{dppm})_{2} \mathrm{Ru}(\mathrm{H})(\mathrm{L})\right]\left[\mathrm{BF}_{4}\right]$ derivatives $\left(\mathrm{L}=\mathrm{P}(\mathrm{OMe})_{3}, \quad \mathrm{P}(\mathrm{OEt})_{3}, \quad \mathrm{PF}\left(\mathrm{O}^{\mathrm{i}} \mathrm{Pr}\right)_{2}\right)$. The cisdisposition of the hydride and the phosphite ligands was ascertained from the ${ }^{1} \mathrm{H}$ and ${ }^{31} \mathrm{P}$ NMR spectral features. The hydride ligand shows a complex multiplet pattern that could be described with a XABCDM spin system in the ${ }^{1} \mathrm{H}$ NMR spectrum whereas the ${ }^{31} \mathrm{P}$ NMR spectrum could be modelled as an ABCDM spin system. In addition, we carried out X-ray crystal structure determination of cis-[(dppm $\left.)_{2} \mathrm{Ru}(\mathrm{H})\left(\mathrm{P}(\mathrm{OMe})_{3}\right)\right]\left[\mathrm{BF}_{4}\right]$ complex, which revealed without any ambiguity the cis-conformation.

The cis- $\left[(\mathrm{dppm})_{2} \mathrm{Ru}(\mathrm{H})\left(\mathrm{P}(\mathrm{OMe})_{3}\right)\right]\left[\mathrm{BF}_{4}\right]$ complex crystallized from a dichloromethanepetroleum ether solution in space group P-1 with cell dimensions $a=9.77640(10) \AA$, $b=15.0833(2) \AA, \quad c=20.72300(10) \AA, \quad$ and $\quad \alpha=75.75^{\circ}, \quad \beta=76 \cdot 1020(10)^{\circ}, \quad \gamma=$ $77 \cdot 1270(10)^{\circ}$. A perspective drawing and the numbering scheme for the cation are shown in figure 1. The structure consists of a severely distorted octahedron: three of the four $\mathrm{dppm}$ phosphorus atoms define a plane whereas, the fourth phosphorus is approximately trans to the phosphite ligand that is perpendicular to the plane of the three dppm phosphorus atoms. The hydride ligand that occupies the sixth coordination site on the metal was not located. The structure could be viewed as a distorted trigonal bipyramid if the hydride ligand is excluded, as shown in the figure. The dppm bite angles, $\mathrm{P}(1)-\mathrm{Ru}(1)-$ $\mathrm{P}(2)$ and $\mathrm{P}(3)-\mathrm{Ru}(1)-\mathrm{P}(4)$ are respectively, 71.40(7) and 70.89(7) ${ }^{\circ}$. The notable feature of the structure is the tightening of the $\mathrm{Ru}(1)-\mathrm{P}(5)$ bond $(2 \cdot 249(2) \AA)$ in comparison to that of the trans-isomer $(2 \cdot 3153(17) \AA)$.

A reasonable mechanism of the isomerization could involve the protonation of one of the dppm phosphorus atoms of trans-[(dppm $\left.)_{2} \mathrm{Ru}(\mathrm{H})(\mathrm{L})\right]\left[\mathrm{BF}_{4}\right]$ complex in the presence of $\mathrm{HBF}_{4} \bullet \mathrm{Et}_{2} \mathrm{O}$. This then allows for the swinging around of the free, protonated end of the dppm ligand to generate a vacant site $c i s$ to the hydride. An intramolecular rearrangement 
renders the phosphite cis to the hydride, followed by the closure of the dppm ring completing the isomerization. The cis isomers could be obtained even in the absence of the acid, under refluxing conditions of $\mathrm{CHCl}_{3}$ solution containing the trans-isomers. A trans to cis product distribution ratio that is dependent on the cone angle of the phosphite ligand was achieved after $20 \mathrm{~h}$ under such conditions: greater cone angle of the phosphite results in greater amount of the cis-isomer. In the absence of the acid, a different mechanism seems to operate: the phosphite due to its labile nature gets released from the metal centre resulting in a coordinatively unsaturated five-coordinate species. The phosphite then attacks the metal center from a position that is cis to the hydride ligand (scheme 1).

The trans $\rightarrow$ cis isomerization that is promoted by acid as discussed above is a rare example of acid-catalysed isomerization in six-coordinate complexes. Since the isomerization is quite facile, it could mean that a relatively low barrier relates the two isomers.

Upon further addition of $\mathrm{HBF}_{4} \cdot \mathrm{Et}_{2} \mathrm{O}$ to the mixture of the trans and the cis$\left[(\mathrm{dppm})_{2} \mathrm{Ru}(\mathrm{H})(\mathrm{L})\right]\left[\mathrm{BF}_{4}\right] \quad\left(\mathrm{L}=\mathrm{P}(\mathrm{OMe})_{3}, \quad \mathrm{P}(\mathrm{OEt})_{3}\right)$, the respective trans and the cisdihydrogen complexes $\left[(\mathrm{dppm})_{2} \mathrm{Ru}\left(\eta^{2}-\mathrm{H}_{2}\right)(\mathrm{L})\right]\left[\mathrm{BF}_{4}\right]_{2}$ were obtained. In the case of the $\mathrm{P}\left(\mathrm{O}^{\mathrm{i}} \mathrm{Pr}\right)_{3}$ hydride complex, the addition of one equiv of acid brings about the isomerization of the trans to the cis-isomer. In addition, a small amount of another

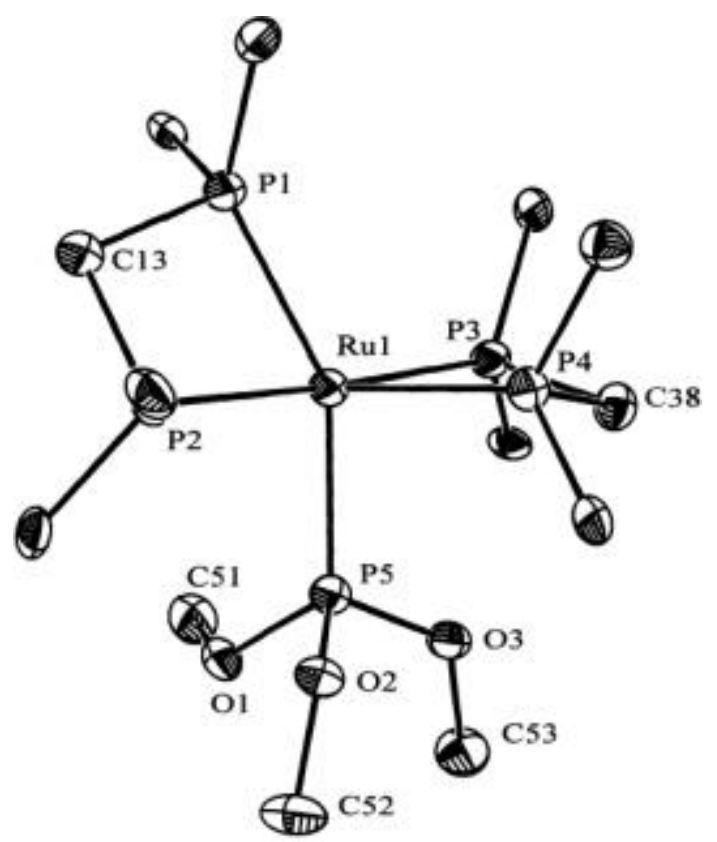

Figure 1. Perspective drawing of cis- $\left[(\mathrm{dppm})_{2} \mathrm{Ru}(\mathrm{H})\left(\mathrm{P}(\mathrm{OMe})_{3}\right)\right]^{+}$cation. The phenyl groups on the dppm phosphorus atoms have been omitted for clarity; only one carbon atom of each of the phenyl groups is shown in the figure. Selected bond lengths $(\AA)$ and angles $\left({ }^{\circ}\right)$ : $\mathrm{Ru}(1)-\mathrm{P}(1) 2 \cdot 379(2), \mathrm{Ru}(1)-\mathrm{P}(2)$ 2.316(2), $\mathrm{Ru}(1)-\mathrm{P}(3) 2 \cdot 349(2)$, $\mathrm{Ru}(1)-\mathrm{P}(4)$ 2.417(2), Ru(1)-P(5) 2.249(2), $\mathrm{P}(5)-\mathrm{Ru}(1)-\mathrm{P}(1)$ 152.14(8), $\mathrm{P}(5)-\mathrm{Ru}(1)-$ $\mathrm{P}(2)$ 90.20(7), $\mathrm{P}(5)-\mathrm{Ru}(1)-\mathrm{P}(3)$ 93.22(7), $\mathrm{P}(5)-\mathrm{Ru}(1)-\mathrm{P}(4)$ 92.15(7), $\mathrm{P}(2)-\mathrm{Ru}(1)-\mathrm{P}(1)$ 71.40(7), $\mathrm{P}(4)-\mathrm{Ru}(1)-\mathrm{P}(3)$ 70.89(7). 


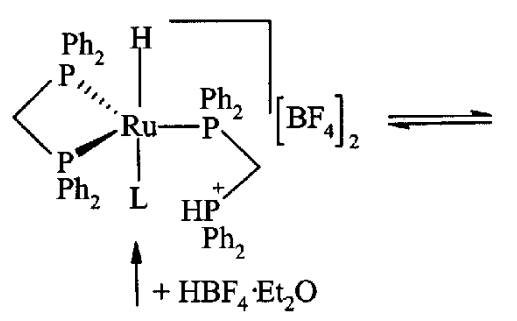

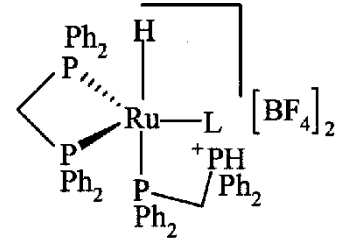

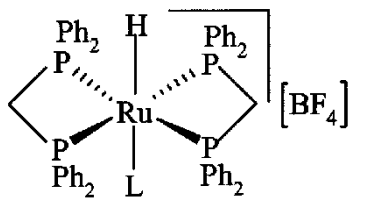<smiles>C1C[AlH]1</smiles>

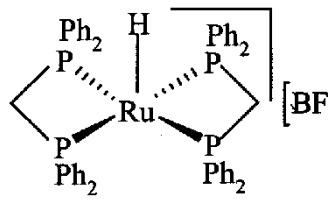

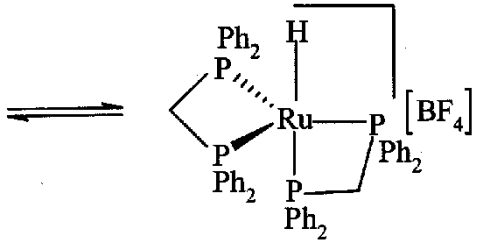<smiles>CCCOCC</smiles>

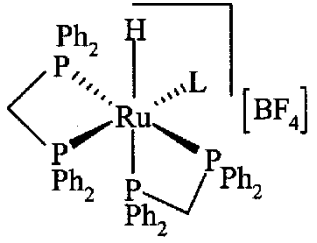

Scheme 1.

hydride derivative, trans- $\left[(\mathrm{dppm})_{2} \mathrm{Ru}(\mathrm{H})\left(\mathrm{PF}\left(\mathrm{O}^{\mathrm{i}} \mathrm{Pr}\right)_{2}\right)\right]\left[\mathrm{BF}_{4}\right]$ was also formed. We reported the mechanism of the formation of an analogous dppe containing species in an earlier report ${ }^{2}$. When further acid was added the respective cis and the trans-dihydrogen complexes $\left[(\mathrm{dppm})_{2} \mathrm{Ru}\left(\eta^{2}-\mathrm{H}_{2}\right)\left(\mathrm{PF}\left(\mathrm{O}^{\mathrm{i}} \mathrm{Pr}\right)_{2}\right)\right]\left[\mathrm{BF}_{4}\right]_{2}$ were obtained. The cone angle reduction (in $\left.\mathrm{PF}\left(\mathrm{O}^{\mathrm{i}} \mathrm{Pr}\right)_{2}\right)$ in the otherwise sterically crowded $\mathrm{P}\left(\mathrm{O}^{\mathrm{i}} \mathrm{Pr}\right)_{3}$ for the generation of the trans-[(dppm $\left.)_{2} \mathrm{Ru}(\mathrm{H})\left(\mathrm{PF}\left(\mathrm{O}^{\mathrm{i} P r}\right)_{2}\right)\right]\left[\mathrm{BF}_{4}\right]$ that could be observed NMR spectroscopically seems a reasonable prospect. The cis- $\left[(\mathrm{dppm})_{2} \mathrm{Ru}\left(\eta^{2}-\mathrm{H}_{2}\right)(\mathrm{L})\right]\left[\mathrm{BF}_{4}\right]_{2}$ complexes are the first examples of dicationic dihydrogen complexes wherein the bound $\mathrm{H}_{2}$ and a monodentate co-ligand are in cis-conformation in the family of compounds of the type $\left[(\text { diphosphine })_{2} \mathrm{Ru}\left(\eta^{2}-\mathrm{H}_{2}\right)(\mathrm{L})\right]^{2+}$.

The intact nature of the $\mathrm{H}-\mathrm{H}$ bond in the dihydrogen complexes was established by the ${ }^{1} \mathrm{H}$ spin-lattice relaxation time measurements, $T_{1}\left(400 \mathrm{MHz}, 298 \mathrm{~K}, \mathrm{CD}_{2} \mathrm{Cl}_{2}\right)$ and the observation and the measurement of the H, D coupling constant of the $\eta^{2}-\mathrm{HD}$ isotopomers.

On the other hand, the protonation of the hydride complexes trans$\left[(\mathrm{dppm})_{2} \mathrm{Ru}(\mathrm{H})(\mathrm{L})\right]\left[\mathrm{BF}_{4}\right]\left(\mathrm{L}=\mathrm{PMe}_{3}, \mathrm{PMe}_{2} \mathrm{Ph}\right)$ with 1 equiv of $\mathrm{HBF}_{4} \bullet \mathrm{Et}_{2} \mathrm{O}$ resulted in the complete disappearance of the starting hydride accompanied by the appearance of trans$\left[(\mathrm{dppm})_{2} \mathrm{Ru}\left(\eta^{2}-\mathrm{H}_{2}\right)(\mathrm{H})\right]\left[\mathrm{BF}_{4}\right]$ and trans-[(dppm $\left.)_{2} \mathrm{Ru}\left(\eta^{2}-\mathrm{H}_{2}\right) \mathrm{Cl}\right]\left[\mathrm{BF}_{4}\right]$ complexes as evidenced in the ${ }^{1} \mathrm{H}$ NMR spectrum. Further addition of the acid led to the disappearance of the hydride dihydrogen complex whereas the dihydrogen chloride complex remained intact. The ${ }^{31} \mathrm{P}$ NMR spectra gave similar indications of the appearance of hydride dihydrogen and dihydrogen chloride followed by the disappearance of the former in the 
presence of excess acid. However, when excess acid was added, two new signals were observed that could be assigned to a coordinatively unsaturated species, $\left[(\mathrm{dppm})_{2} \mathrm{RuCl}\right]^{+}$.

Most of the catalytic hydrogenation reactions involve dihydrogen complex intermediates which protonate adjacent alkyls in a $\sigma$ bond metathesis reaction ${ }^{9}$. The mechanisms of such reactions are poorly understood. In this context, the cis$\left[(\mathrm{dppm})_{2} \mathrm{Ru}\left(\eta^{2}-\mathrm{H}_{2}\right)(\mathrm{L})\right]\left[\mathrm{BF}_{4}\right]_{2}$ complexes serve as good starting material to study the mechanisms of such reactions as follows: the ligand $\mathrm{L}$ cis to the dihydrogen moiety in cis-[(diphosphine $\left.)_{2} \mathrm{Ru}\left(\eta^{2}-\mathrm{H}_{2}\right)(\mathrm{L})\right]^{n+}$ could be replaced with alkyls so that the $\sigma$-alkyl group could accept $\mathrm{H}^{+}$via a heterolytic cleavage of the bound $\mathrm{H}_{2}$. Intermediates enroute to the proton transfer could be studied using NMR spectroscopy. Efforts in this direction are underway in our laboratories.

\section{Acknowledgements}

We are grateful to the Council of Scientific and Industrial Research (early parts of this work) and the Department of Science and Technology, India (later parts of this work) for financial support. N M thanks CSIR for a fellowship. We also thank the Sophisticated Instruments Facility, IISc for the NMR spectral data and Prof. C N R Rao and Dr G U Kulkarni (JNCASR) for allowing us to use the X-ray diffractometer facility.

\section{References}

1. Tolman C A 1977 Chem. Rev. 77313

2. Mathew N, Jagirdar B R, Gopalan R S and Kulkarni G U 2000 Organometallics 194506

3. Cappellani E P, Drouin S D, Jia G, Maltby P A, Morris R H and Schweitzer C T 1994 J. Am. Chem. Soc. 1163375

4. Chin B, Lough A J, Morris R H, Schweitzer C T and D'Agostino C 1994 Inorg. Chem. 33 6278

5. Kubas G J 1988 Acc. Chem. Res. 21120

6. Crabtree R H 1990 Acc. Chem. Res. 2395

7. Jessop P G and Morris R H 1992 Coord. Chem. Rev. 121155

8. Heinekey D M and Oldham W J Jr 1993 Chem. Rev. 93913

9. Crabtree R H 1993 Angew. Chem., Int. Ed. Engl. 32789

10. Morris R H 1996 Can. J. Chem. 741907 